\title{
Pengenalan Pendidikan dan Profesi Tenaga Kesehatan Rumah Sakit pada Siswa SMA Guna Mengembangkan Wawasan Dunia Karir
}

\author{
Dina Fitriana $\mathbf{R}^{{ }^{*}}$, Rawi Miharti ${ }^{2}$ \\ ${ }^{1,2}$ Program Studi Rekam Medis, Departemen Layanan dan Informasi Kesehatan, Sekolah \\ Vokasi, Universitas Gadjah Mada \\ *Email: dinafitriana.r@ugm.ac.id
}

\begin{abstract}
Abstrak
Perguruan tinggi adalah salahsatu stakeholder yang turut berperan dalam menyiapkan usia produktif berkualitas melalui tri dharma. Keberhasilan menyiapkan generasi pada tingkat SMA akan dapat menunjang keberhasilan Indonesia di tahun 2030. Diharapkan dengan usia, energi dan semangat besar maka menjadi modal besar bagi pembangunan negara. Tujuan dalam kegiatan ini adalah untuk mendorong tumbuhnya kesadaran pelajar dalam merencakan pendidikan lanjut ataupun karirnya sebagai gambaran rencana kehiupan masa yang akan datang serta meningkatkan pengetahuan wawasan sisiwa siswi terkait pendidikan dan profesi tenaga kesehatan utamanya di rumah sakit yang begitu kompleks. Metode dalam pelaksanaan kegiatan ini adalah dengan penyuluhamn, diskusi dan tanya jawab. Kegiatan dilaksanakan pada Hari Jumat, 11 Agustus 2017 pukul 13.00 - 15.0o WIB di SMA Negeri 2 Wates Kulon Progo Yogyakarta. Kegiatan pengenalan pendidikan dan profesi tenaga kesehatan berupa penyuluhan penjelasan ini diikuti oleh 131 siswa siswi SMA N 2 Wates Kulon Progo yang merupakan pelajar kelas XII jurusan IPA dan IPS SMA N 2 Wates Kulon Progo. Kegiatan ini berlangsung dengan melibatkan beberapa pihak yakni tim dosen dan mahasiswa Prodi Rekam Medis, kepala sekolah dan guru bimbingan konseling (BK) serta siswa siswi kelas XII di SMA Negeri 2 Wates Kulon Progo. Para peserta mengikuti kegiatan dengan baik, aktif dan penuh antusias.
\end{abstract}

Kata Kunci: Pendidikan Profesi Kesehatan, Wawasan Karir, Profesi Tenaga Kesehatan

\begin{abstract}
Higher education is one of the stakeholders which have a role in preparing quality productive age through Tri Dharma. The success of preparing a generation at the senior high school level will be able to support Indonesia's success in 2030. It is expected that with age, energy and great enthusiasm it will become a big capital for the country's development. The purpose of this activity is to encourage the growth of student awareness in planning further education or career as a description of future life plans and to increase knowledge about the insights of female students related to education and the health professionals especially in complex hospitals. The method in implementing this activity is by counseling, discussion and question and answer. The activity was held on Friday, 11 August 2017 at 1:00 p.m. - 3:00 p.m. WIB at SMA (Senior High School) 2 Wates in Kulon Progo Yogyakarta. The introduction of education and the profession of the health workforce in the form of explanatory counseling was attended by 131 students of SMA N 2 Wates who were students of class XII majoring in Science and Social Sciences at SMA N 2 Wates. This activity took place by involving several parties, namely the lecturer and student team of Medical Record Study Program, headmaster and counseling teacher (BK) as well as class XII students at SMA N 2 Wates in Kulon Progo. The participants took part in the activity well, actively and enthusiastically.
\end{abstract}

Keywords: Health Professional Education, Career Insight, Health Worker Professionals 


\section{PENDAHULUAN}

Siswa siswi Sekolah Menengah Atas merupakan anak didik sebagai generasi penerus harapan bangsa Indonesia. Remaja sebagai generasi penerus memiliki kemampuan potensial yang bisa diolah menjadi kemampuan actual. Selain itu juga memiliki potensi kecerdasan intelektual, emosi dan sosial, berbahasa, dan keserdasan seni yang bisa diolah menjadi kecerdasan aktual yang dapat membawa mereka kepada prestasi yang tinggi dan kesuksesan.

Kehidupan yang lebih baik bagi generasi penerus tersebut didukung dengan adanya kebutuhan pendidikan. Menurut Undang-undang Sistem Pendidikan Nasional nomor 20 tahun 2003 pasal 1 ayat (1): "Pendidikan adalah usaha sadar dan terencana untuk mewujudkan suasana belajar dan proses pembelajaran agar peserta didik secara aktif mengembangkan potensi dirinya untuk memiliki kekuatan spiritual keagamaan, pengendalian diri, kepribadian, kecerdasan, akhlak mulia, serta keterampilan yang diperlukan dirinya, masyarakat, bangsa dan negara. Dengan demikian diharapkan mereka dapat menjadi harapan bangsa yang memiliki kemampuan bahkan keahlian dalam bekerja berkarya dan memenuhi kehidupannya baik itu bersifat materi maupun imateri.

Perguruan tinggi adalah salahsatu stakeholder yang turut berperan serta dalam menyiapkan usia produktif berkualitas melalui tri dharma pendidikan. Keberhasilan menyiapkan generasi yang sekarang bersekolah pada tingkat SMA akan dapat menunjangkeberhasilan Indonesia di tahun 2030. Diharapkan dengan usia, energi dan semangat yang begitu besar maka menjadi modall besar bagi pembangunan negara. Bidang dalam pendidikan dan terkait profesi sangat beragam jenisnya, dimana bidang kesehatan adalah salahsatunya. Dalam bidang kesehatan suatu pendidikan kesehatan diberikan dengan harapan dapat membentuk kemampuan ahli yang nantinya dapat berperan di dunia kesehatan yakni di sarana pelayanan kesehatan ataupun dunia pendidikan kesehatan. Dimana dunia bidang kesehatan ke depan dipandang akan selalu prospek, karena bagaimanapun juga kesehatan merupakan kebutuhan dasar bagi setiap manusia.

Dalam hal ini upaya untuk membangun wawasan pengetahuan dan kesadaran individu dan masyarakat utamanya pada golongan generasi penerus bangsa yakni khususnya anak sekolah tingkat menengah atas atau SMA perlu diberikan adanya pengenalan pendidikan dan profesi, utamanya di bidang kesehatan.

Sekolah Menengah Atas Negeri 2 Wates merupakan salah satu sekolah yang terletak di wilayah Kulon Progo, Daerah Istimewa Yogyakarta. SMA Negeri 2 Wates memiliki jumlah murid yang cukup banyak dengan dibagi menjadi dua penjurusan yaitu kelas IPS dan IPA. Dalam hal ini, besar peluang untuk diadakan suatu pengabdian masyarakat terkait pendidikan dan profesi tenaga kesehatan utamanya di Rumah Sakit untuk mengembangkan wawasan sebagai bekal siswa siswi dalam nantinya memilih jurusan ketika memasuki pendidikan selanjutnya yakni perguruan tinggi, lebih lanjut pada perencanaan pemilihan profesi di masa depan.

\section{METODE}

Program pengabdian masyarakat sekolah vokasi UGM dengan judul Pengenalan Pendidikan dan Profesi Tenaga Kesehatan Rumah Sakit Pada Siswa SMA Guna Mengembangkan Wawasan Dunia Karir, akan dilakukan dengan menggunakan metode sebagia berikut :

1. Penyuluhan, diskusi dan tanyajawab

Penyuluhan dilakukan untuk memberikan wawasan gambaran pendidikan dan profesi serta peran tenaga kesehatan utamanya di rumah sakit yang begitu kompleks.

2. Survey

Survey dilakukan ketika tahap persiapan pengabdian masyarakat dan ketika pelaksanaan. Dimana survey ketika pelaksanaan untuk mengetahui sejauh mana pandangan perencanaan karir siswa - siswi SMA, termasuk 
pengetahuan siswa-siswi terkait tenaga kesehatan di Rumah Sakit.

\section{HASIL DAN PEMBAHASAN}

Kegiatan pengabdian masyarakat ini dilaksanakan pada Hari Jumat, 11 Agustus 2017 pukul 13.00 - 15.00 WIB di Aula SMA Negeri 2 Wates Kulon Progo Yogyakarta. Kegiatan pengenalan pendidikan dan profesi tenaga kesehatan berupa penyuluhan penjelasan ini diikuti oleh 131 siswa siswi SMA N 2 Wates Kulon Progo (dari jumlah total 158 siswa) yang merupakan siswa siswi kelas XII jurusan IPA dan IPS SMA N 2 Wates Kulon Progo.

Kegiatan ini berlangsung dengan melibatkan beberapa pihak yakni tim dosen dan mahasiswa Prodi D3 Rekam Medis SV UGM, pihak kepala sekolah dan guru bimbingan konseling (BK) serta siswa siswi kelas XII di SMA Negeri 2 Wates Kulon Progo. Para peserta mengikuti kegiatan dengan baik, aktif dan penuh antusias.

Acara pengabdian kepada masyarakat ini dimulai pukul 13.00 WIB, tepat pada waktu tersebut pembawa acara mulai membuka acara yang dimulai dengan doa dengan harapan kegiatan tersebut dapat berjalan dengan baik dan lancar. Kemudian pembawa acara membacakan serangkaian kegiatan yang akan berlangsung selama kegiatan pengabdian masyarakat.

Sambutan dilakukan oleh salah satu guru Bimbingan Konseling (BK) SMA Negeri 2 Wates Kulon Progo yaitu Ibu Cresti S., S.Pd., M.Si. Adanya kegiatan pengabdian kepada masyarakat ini disambut dengan baik. Dalam sambutannya perwakilan SMA Negeri 2 Wates Kulon Progo menyampaikan rasa terima kasih pada pihak Sekolah Vokasi UGM yang telah berkenan berbagi ilmu dan pengetahuan kepada siswa siswi kelas XII di SMA Negeri 2 Wates Kulon Progo. Beliau berharap nantinya dapat menambah wawasan siswa siswi.

Sambutan dilakukan oleh perwakilan Kepala Program Studi D3 Rekam Medis SV UGM yaitu Angga Eko Pramono, SKM., MPH. Pihak perwakilan dari Prodi menyampaikan ucapan terima kasih atas kerjasamaya yang baik dan semoga kegiatan pengabdian kepada masyarakat ini lancar dan membawa manfaat untuk kebaikan serta kemajuan bersama. Disamping itu

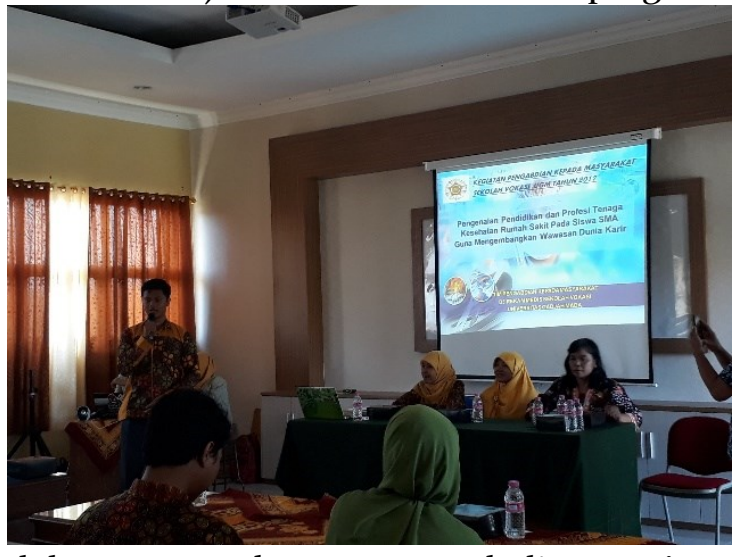

dalam sambutannya beliau juga menyampaikan bahwa kegiatan pengabdian kepada masyarakat merupakan kegiatan rutin yang dilakukan oleh program studi guna lebih dekat dengan masyarakat dan berbagi ilmu yang bermanfaat.

Acara sambutan dari pihak Prodi $\mathrm{D}_{3}$ Rekam Medis Sekolah Vokasi UGM dilanjutkan dengan penyerahan plakat souvenir kepada pihak Dinas Kesehatan Kabupaten Kulon Progo yang menyimbolkan adanya suatu kerjasama yang baik anatara kedua pihak. Suasana sambutan dan penyerahan plakat berlangsung tertib dan sesuai agenda perencanaan acara.

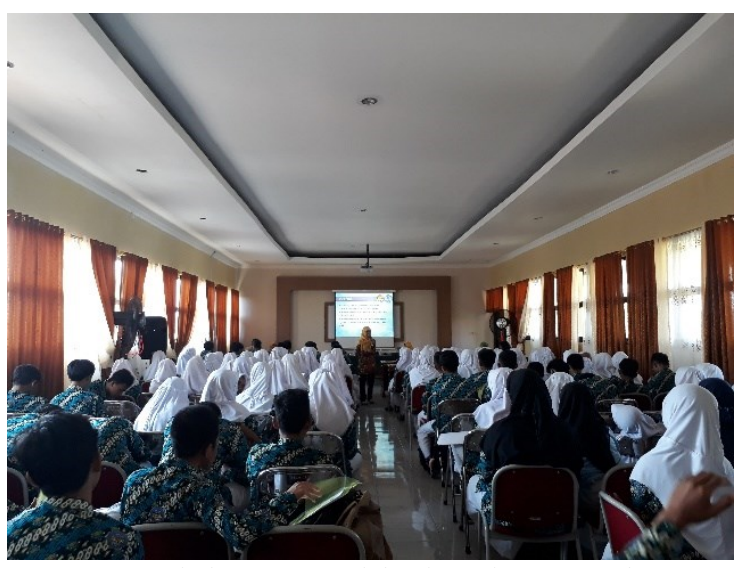

Setelah acara dibuka dan sambutansambutan serta pemberian plakat, maka acara inti dimulai yakni penyampaian materi pengenalan pendidikan dan profesi tenaga kesehatan rumah sakit pada siswa SMA guna mengembangkan wawasan dunia karir.. Penyampaian materi pertama dilakukan oleh Ketua Tim Pelaksana 
Pengabdian Masyarakat yaitu Dina Fitriana Rosyada, SKM., MKL. Selanjutnya diisi oleh pemateri kedua yaitu oleh Ibu Rawi Miharti, $\mathrm{MPH}$. Adapun materi konsep yang disampaikan oleh keduapemateri antara lain sebagai berikut :
1. Pengenalan Tim Pengabdian Masyarakat Prodi Rekam Medis SV UGMtian Sistem, Sistem Informasi

2. Nilai penting pendidikan dan pendidikan profesi

3. Pengenalan definisi profesi, profesionalisme, karir dan keterkaitannya dengan nilai penting perencanaan karir

4. Pemutaran video perencanaan karir dan profesi

5. Prospektus peluang karir tenaga kesehatan

6. Tenaga kesehatan dan organisasi profesinya

7. Pendidikan dan profesi kesehatan di Rumah Sakit

8. Hal terkait pengenalan rekam medis

Materi konsep dasar disampaikan dengan media perantara slide power point oleh ketua tim pelaksana pengabdian. Disamping itu diputarkan video mengenai pentingnya melakuakan perencanaan karir dan prioritas nilai penting terhadap profesi. Ketika acara berlangsung peserta juga aktif bertanya dan menjawab pertanyaan.

Kegiatan pengabdian kepada masyarakat berupa pelatihan ini berjalan baik dan lancar. Peserta perwakilan dari kelas XII jurusan IPA dan IPS di SMA Negeri 2 Wates Kulon Progo mengikuti dengan aktif dan penuh antusias. Dari peserta yang hadir cukup banyak yang mengajukan pertanyaan dan juga menjawab pertanyaan seputar profesi kesehatan. Beberapa diantaranya memberikan kesan dan pendapatnya mengenai adanya kegiatan tersebut, dimana belum pernah diadakan sebelumnya. Peserta merasakan bahwa dengan adanya kegiatan tersebut dapat mengembangkan pengetahuan dan memberi kesadaran pentingnya merencanakan karir dan studi ke depan. Rangkaian demi rangkaian acara kegiatan pengabdian kepada masyarakat yang berupa pelatihan singkat ini dapat berjalan dengan baik, tertib meski ditemukan kendala teknis. Selesai acara pembagian souvenir, pihak pemateri memberikan apresiasi kepada peserta yang sangat tinggi semangatnya, tinggi keingintahuannya terhadap nilai penting perencanaan karir dan prospektus karir tenaga kesehatan. Para peserta berpendapat senang sekali bisa mengikuti kegiatan tersebut.

Acara ditutup dengan doa sesuai dengan keyakinan masing-masing, kemudian diakhiri dengan sesi pengabadian kegiatan tersebut dengan melakukan foto bersama-sama dan saling bersalaman pamit sebelum pulang. Terasa singkat kegiatannya namun memberikan kesan yang baik untuk semuanya, rasa haru dan senang bisa saling berbagai ilmu pengetahuanpun sangat terasa ketika itu.

\section{SIMPULAN}

Kegiatan pengabdian masyarakat telah terealisasi dengan baik. Pihak SMA N 2 Wates Kulon Progo mendukung terlaksananya kegiatan ini. Siswa siswi SMA $\mathrm{N}_{2}$ Wates pada umumnya lebih mengetahui pendidikan sarjana $\left(\mathrm{S}_{1}\right)$ dibandingkan pendidikan vokasional. Dengan adanya sosialisasi pendidikan vokasional siswa siswidapat mengetahui mengenai pendidikan vokasional khususnya pada kegiatanini adalah terkait bidang rekam medis. Siswa siswi SMA N 2 Wates Kulon Progo pada umumnya mengetahui pendidikan dan profesi bidang kesehatan berupa kedokteran, kebidanan, keperawatan, ahli gizi, namun tenaga kesehatan yang secara spesifik yang lainnya belum banyak mengetahui termasuk mengenai jurusan RMIK. Dengan adanya sosialisasi mengenai pendidikan dan profesi tenaga kesehatan di sekolah utamanya SMA maka dapat menambah wawasan prospektus karir bidang kesehatan. Peserta sangat antusias dengan kegiatan ini karena hal baru dan langka bagi mereka. Pengadaan waktu lebih dalam beberapa hari yang berkelanjutan untuk kegiatan tersebut seingga bisa cukup dipantau perkembangan siswa-siswi dalam perencanaan karier. 


\section{DAFTAR PUSTAKA}

Hatta R, Gemala. (2009). Manajemen Informasi Kesehatan. Jakarta: selemaba

Huffman, E, K. (1994). Health Information Management. Berwyn: Psycians Record Company.

Menkes RI. (2008). Permenkes RI.Nomor 269/MENKES/PER/III/2008. Jakarta: Menkes RI.

Permenkes No.340/MENKES/PER/III/2010. Tentang Klasifikasi Rumah Sakit.

Undang-Undang Republik Indonesia No. 44 Tahun 2009 Tentang Rumah Sakit.

Undang-Undang Sistem Pendididkan Nasional No. 20 Tahun 2003. 
